\title{
An update on the use of inositols in preventing gestational diabetes mellitus (GDM) and neural tube defects (NTDs)
}

Fabio Facchinetti, Pietro Cavalli, Andrew J. Copp , Rosario D'Anna, Eleni Kandaraki , Nicholas D.E. Greene \& Vittorio Unfer for The Experts Group on Inositol in Basic and Clinical Research

To cite this article: Fabio Facchinetti , Pietro Cavalli , Andrew J. Copp , Rosario D'Anna, Eleni Kandaraki , Nicholas D.E. Greene \& Vittorio Unfer for The Experts Group on Inositol in Basic and Clinical Research (2020): An update on the use of inositols in preventing gestational diabetes mellitus (GDM) and neural tube defects (NTDs), Expert Opinion on Drug Metabolism \& Toxicology, DOI: $10.1080 / 17425255.2020 .1828344$

To link to this article: https://doi.org/10.1080/17425255.2020.1828344

Accepted author version posted online: 23 Sep 2020.

Submit your article to this journal ๔

山 Article views: 15

Q View related articles $\longleftarrow$

View Crossmark data 
Publisher: Taylor \& Francis \& Informa UK Limited, trading as Taylor \& Francis Group Journal: Expert Opinion on Drug Metabolism \& Toxicology

DOI: $10.1080 / 17425255.2020 .1828344$

Review

An update on the use of inositols in preventing gestational diabetes mellitus (GDM) and neural tube defects (NTDs)

Fabio Facchinetti ${ }^{1}{ }^{*}$, Pietro Cavalli ${ }^{2}$, Andrew J. Copp ${ }^{3}$, Rosario D'Anna ${ }^{4}$, Eleni Kandaraki ${ }^{5}$, Nicholas D.E. Greene $^{3}$, Vittorio Unfer ${ }^{6}$ for "The Experts Group on Inositol in Basic and Clinical Research"

${ }^{1}$ Unit of Obstetrics and Gynecology, Mother-Infant Department, University of Modena and Reggio Emilia, Italy

${ }^{2}$ Clinical Genetics, ASST - Bergamo Est, Italy

${ }^{3}$ Newlife Birth Defects Research Centre and Developmental Biology \& Cancer Research and Teaching Department, Great Ormond Street Institute of Child Health, University College London, London, United Kingdom

${ }^{4}$ Department of Human Pathology, University of Messina, Messina, Italy ${ }^{5}$ Department of Endocrinology \& Diabetes, HYGEIA Hospital, Marousi, Athens, Greece

${ }^{6}$ Department of Experimental Medicine, Sapienza University of Rome, Rome, Italy

*Corresponding author: Fabio Facchinetti,, Unit of Obstetrics and Gynecology, Mother-Infant Department, University of Modena and Reggio Emilia, Italy, email: facchi@unimore.it 
"The Experts Group on Inositol in Basic and Clinical Research"

Fabio Facchinetti ${ }^{1}$, Vittorio Unfer ${ }^{2}$, Marialuisa Appetecchia ${ }^{3}$, Cesare Aragona ${ }^{4}$, Matteo Bertelli ${ }^{5}$, Arturo Bevilacqua ${ }^{6}$, Maria Salome Bezerra Espinola ${ }^{7}$, Mariano Bizzarri ${ }^{8}$, Pietro Cavalli ${ }^{9}$, Andrew Copp ${ }^{10}$, Rosario $D^{\prime} A n n a^{11}$, Didier Dewailly ${ }^{12}$, Nicholas Greene ${ }^{13}$, Imelda Hernández Marín ${ }^{14}$, Zdravko A. Kamenov ${ }^{15}$, Eleni Kandaraki ${ }^{16}$, Evanthia Diamanti-Kandarakis ${ }^{17}$, Antonio Simone Laganà ${ }^{18}$, Giovanni Monastra ${ }^{19}$, Mario Montanino Oliva ${ }^{20}$, John E. Nestler ${ }^{21}$, Ali Cenk Ozay ${ }^{22}$, Olga Papalou ${ }^{23}$, Lali Pkhaladze ${ }^{24}$, Giusy Porcaro ${ }^{25}$, Nikos Prapas ${ }^{26}$, Christophe O. Soulage ${ }^{27}$, Annarita Stringaro ${ }^{28}$, Mónica Vazquez-Levin ${ }^{29}$, Artur Wdowiak ${ }^{30}$.

${ }^{1}$ Unit of Obstetrics and Gynecology, Mother-Infant Department, University of Modena and Reggio Emilia, Italy

${ }^{2}$ Department of Experimental Medicine, Sapienza University of Rome, Rome, Italy

${ }^{3}$ Oncological Endocrinology Unit - Regina Elena National Cancer Institute -IRCCS, Rome, Italy

${ }^{4}$ Systems Biology Group Lab - Department of Experimental Medicine, Sapienza University of Rome, Rome, Italy

${ }^{5}$ EBTNA-Lab, Via Delle Maioliche, 57/G, 38068, Rovereto, TN, Italy; MAGI's Lab, Via Delle Maioliche, 57/D, 38068, Rovereto, TN, Italy; MAGI

${ }^{6}$ Department of Dynamic and Clinical Psychology, Sapienza University of Rome, Rome, Italy

${ }^{7}$ Systems Biology Group Lab - Department of Experimental Medicine, Sapienza University of Rome, Rome, Italy

${ }^{8}$ Department of Experimental Medicine, Systems Biology Group, University La Sapienza, Rome, Italy

${ }^{9}$ Clinical Genetics, ASST - Bergamo Est, Italy

${ }^{10}$ Newlife Birth Defects Research Centre and Developmental Biology \& Cancer Programme, GOS Institute of Child Health, University College London, United Kingdom

${ }^{11}$ Department of Human Pathology, University of Messina, Messina, Italy

${ }^{12}$ Faculty of Medicine, University of Lille, Lille, France - INSERM, Laboratory of Development and Plasticity of the Neuroendocrine Brain, Jean-Pierre Aubert Research Centre, Lille, France

${ }^{13}$ Newlife Birth Defects Research Centre and Developmental Biology \& Cancer Programme, Institute of Child Health, University College London, London, United Kingdom

${ }^{14}$ Human Reproduction Department, Hospital Juárez de México, México City - Universidad Nacional

Autónoma de México (UNAM), México City, México.

${ }^{15}$ Department of Internal Medicine, Medical University of Sofia, Sofia - Bulgaria

${ }^{16}$ Department of Endocrinology \& Diabetes, HYGEIA Hospital, Marousi, Athens, Greece

${ }^{17}$ Department of Endocrinology \& Diabetes, HYGEIA Hospital, Marousi, Athens, Greece

${ }^{18}$ Department of Obstetrics and Gynecology, "Filippo Del Ponte" Hospital, University of Insubria, Varese, Italy.

${ }^{19}$ Systems Biology Group Lab - Department of Experimental Medicine, Sapienza University of Rome, Rome, Italy

${ }^{20}$ Department of Obstetrics and Gynecology Santo Spirito Hospital Rome, Italy

${ }^{21}$ Division of Endocrinology, Diabetes and Metabolism, Department of Internal Medicine, Virginia

Commonwealth University, Richmond, VA, USA.

${ }^{22}$ Near East University, Faculty of Medicine, Department of Obstetrics and Gynecology, Nicosia Cyprus -

Near East University, Research Center of Experimental Health Sciences, Nicosia, Cyprus.

${ }^{23}$ Department of Endocrinology \& Diabetes, HYGEIA Hospital, Marousi, Athens, Greece

${ }^{24}$ Ioseb Zhordania Institute of Reproductology, Tbilisi, Georgia

${ }^{25}$ Women's Health Center, USL Umbria 2, Orvieto, Italy

${ }^{26} 3$ rd department of OB-GYNAE, Aristotle University of Thessaloniki, Greece - IAKENTRO Fertility Centre, IVF laboratory, Thessaloniki, Greece

${ }^{27}$ University of Lyon, INSERM U1060, CarMeN, INSA de Lyon, Université Claude Bernard Lyon 1,

Villeurbanne, France 
${ }^{28}$ National Center for Drug Research and Evaluation -Italian National Institute of Health, Rome, Italy. ${ }^{29}$ National Council of Scientific and Technical Research - Instituto de Biología y Medicina Experimental (IBYME) - Buenos Aires, Argentina

${ }^{30}$ Diagnostic Techniques Unit, Medical University of Lublin, Poland.

\section{Abstract}

Introduction: Obstetric history and maternal body composition and lifestyle may be associated with serious complications both for the mother, such as gestational diabetes mellitus (GDM), and for the fetus, including congenital malformations such as neural tube defects (NTDs).

Areas covered: In view of the recent knowledge, changes of nutritional and physical activity habits ameliorate glycemic control during pregnancy and in turn improve maternal and neonatal health outcomes. Recently, a series of small clinical and experimental studies indicated that supplementation with inositols, a family of insulin sensitizers, was associated with beneficial impact for both GDM and NTDs.

Expert opinion: Herein, we discuss the most significant scientific evidence supporting myo-inositol administration as a prophylaxis for the above-mentioned conditions.

Keywords: D-chiro-inositol (DCI); gestational diabetes mellitus (GDM); insulin resistance; myo-inositol (MI); neural tube defects (NTDs); prevention. 


\section{Introduction}

Several factors can be decisive in the onset of unfavorable maternal and fetal outcomes, lifestyle among them [1]. In particular, poor maternal nutritional habits, and especially a lack of glycemic control, may represent leading causes of complications including gestational diabetes mellitus (GDM), large for gestation age babies (LGA) [2,3] and congenital abnormalities affecting the fetal central nervous system, namely neural tube defects (NTDs) [4].

Recent scientific evidence $[5,6]$ has shown that the supplementation of inositols is correlated with achievement of a healthy pregnancy. In particular, myo-inositol (MI) may prevent the onset of GDM as well as reduce the risk of recurrence of NTDs. Here, the authors have gathered data from their own and others' studies to provide an overview of up-to-date knowledge on the mechanisms by which MI may prevent GDM and NTDs, and the implications of these findings for future clinical practice.

\section{The inositols family}

\subsection{Biochemical properties}

Inositols are sugar alcohols (polyols) that occur in 9 different stereoisomeric forms. MI, the most common naturally occurring one, can be transformed into numerous derivatives mainly through either epimerization or phosphorylation of one or several of its hydroxyl groups. The conversion to D-chiro-, scyllo-, muco-, neooccurs by means of specific epimerases. In particular, the conversion rate of $\mathrm{MI}$ to D-chiro-inositol (DCI) ranges from $7 \%$ to about $9 \%$, as measured by the analysis of radiolabeled [3H]-MI, whereas the production of other isomers is minimal, not exceeding $0.06 \%$ of total radiolabeled MI [7]. The human body can actively synthetize MI: in particular, the kidneys produce up to $4 \mathrm{~g} /$ day [8]. Ml derives from the isomerization of glucose-6-phosphate (G6P) to inositol-3-phosphate (Ins3P) by the enzyme D-3-myo-inositol-phosphate synthase (inositol synthase, Ino1 or MIPS1) [9]. Then, inositol-3-phosphate is dephosphorylated to free MI by means of inositol-monophosphatase-1 (IMPA-1 or IMPase) [10]. Free MI can also be generated by the recycling of inositol-1,4,5-trisphosphate (InsP3) and inositol-1,4-bisphosphate (InsP2) generated in inositol phosphate signaling [11]. Endogenous production of $\mathrm{MI}$ and $\mathrm{DCl}$ varies depending on tissue-specific needs [12], and it is known that certain organs, such as brain, need high MI concentrations (10- to 15-fold higher values than are detected in blood) [9].

Inositol transporters are responsible for uptake and intracellular distribution of inositol. They were classified in two groups according to their transport mechanism. Sodium/myo-inositol cotransporter 1 and 2 (SMIT1 and SMIT2) are coupled with sodium ions while proton/myo-inositol cotransporter (HMIT), coupled with protons [13]. They have a different tissue distribution. So far, only SMIT2 was detected in the duodenum and jejunum, the two districts of intestine where they were found [14].

\subsection{Physiological activities}

Inside the cells, inositols are not only present as free molecules, but also as components of membrane phosphoinositides (inositol-containing lipids), including phosphatidyl-inositol phosphate and phosphatidylinositol bisphosphate (PIP2), both compounds with important physiological roles [15]. Hydrolysis of PIP2 by phospholipase C (PLC) produces inositoltrisphosphate (Ins-1,4,5P3, InsP3), which regulates activities of hormones such as FSH, TSH and insulin as a second messenger [15]. The interaction between InsP3 and the membrane receptors of mitochondria and endoplasmic reticulum stimulates calcium influx into the cytosol. This leads the activation of protein kinase $C$ (PKC) and mediates specific cellular responses. Inositols are involved in insulin signaling, with both $\mathrm{MI}$ and $\mathrm{DCl}$ functioning as insulin second messengers, although they mediate different actions of insulin in humans $[16,17,18,19]$. There is an interplay between MI uptake and cellular glucose uptake, and MI content is elevated in tissues such as brain, heart and ovary that have high glucose utilization and consumption $[18,20]$. MI also inhibits adenylate cyclase, thus reducing the release of free fatty acids from adipose tissues [21]. Conversely, DCl levels are elevated in tissues specialized in glycogen storage, including liver, muscle and fat, whereas DCl has low abundance in tissues with high glucose utilization [7].

DCl and MI glycans (IPG-P and IPG-A, respectively) shift glucose metabolism towards glycogen synthesis or glucose catabolism, respectively. In the latter case, MI enhances phosphate-dehydrogenase activity (PDH), 
thus stimulating pyruvate catabolism. IPG-P seems preferentially produced in metabolic stress, following an increase of insulin release. Indeed, after insulin stimulation, $\mathrm{MI}$ is transformed into DCl, through an NAD$\mathrm{NADH}$-dependent epimerase, to maintain a suitable MI:DCI ratio, as required for tissue metabolism [19, 22, 23].

MI significantly inhibits glucose duodenal absorption and therefore counteracts a rise in blood glucose. This finding can be explained by a mutual interference of intestinal uptake by $\mathrm{MI}$ and glucose $[19,24]$. In addition to the above-cited effects, $\mathrm{MI}$ also acts as one of the FSH second messengers in the ovary, as well as of the TSH in the thyroid, both mechanisms mediated by adenylate cyclase [19, 25].

\subsection{Pharmacokinetics}

Some patients, identified as "inositol-resistant", exhibit a weaker than normal response to MI treatment, owing to poor absorption by the oral route.

Aiming to improve MI clinical efficacy, Monastra et al planned a pharmacokinetics study [26] in human healthy volunteers to test the effects of $\alpha$-LA on MI bioavailability, considering the wide range of $\alpha-L A$ activities, especially the effects on improved mineral bioavailability [27].

When administered alone, $\mathrm{Ml}$ average peak plasma concentration at $180 \mathrm{~min}$ increased about threefold versus the baseline, whereas when associated to $\alpha$-LA, it augmented fourfold.

After administration of $\mathrm{MI}$ and $\alpha$-LA, $\mathrm{MI}$ plasma concentrations were significantly higher than after administration of $\mathrm{MI}$ alone: the increase of $\mathrm{Cmax}(\mu \mathrm{mol} / \mathrm{l})$ was $32.4 \%$, while $\mathrm{AUC}(0-300)$ increased by $27.5 \%$ [26].

Moreover, with the aim to explain the mechanism underlying this effect, the authors carried out an in vitro experiment. In detail, they observed that in the presence of digested $\alpha$-LA, MI passage across a monolayer of human Caco-2 cells, used to simulate the intestinal barrier, significantly increased, thereby achieving a higher plasma concentration compared with MI administration alone [26].

This combination of MI with $\alpha$-LA has proven to be useful for improving the treatment of Polycystic Ovary Syndrome (PCOS) MI-resistant patients [28]. A goal for the future will be to investigate further this combination of $\mathrm{MI}$ and $\alpha$-LA, for its ability to enhance the potential beneficial effects of $\mathrm{MI}$ on complex pathologies, such as GDM and NTDs (described below).

\section{The safety profile of inositols}

Before discussing the efficacy of inositols in some pathological conditions, it is important to consider the available data on inositol's safety as a supplement. As stated by the United States Food and Drug Administration (FDA), $\mathrm{Ml}$ is included in the list of compounds that are 'generally recognized as safe' (GRAS). This means inositol has proven to be free of side-effects and, importantly, is safe for use in pregnancy [19, 29].

A recent meta-analysis on 965 pregnant women affected by GDM, who were randomized to receive MI, placebo or no treatment, revealed no adverse maternal events, and no congenital malformations in the fetuses or newborns [30]. Moreover, a Cochrane Review of the relationship between inositol and GDM reported no adverse events associated with inositol antenatal supplementation [31].

\section{MI in management of GDM}

\subsection{GDM diagnosis}

GDM, defined as glucose intolerance solely diagnosed during pregnancy, is characterized by increased insulin resistance and hyperglycemia. It represents a worldwide public health problem with a variable prevalence ranging from 2 to 30\%, depending on the diagnostic criteria and the population studied [32]. Several clinical risks have been associated with GDM, both for the mother, such as hypertension, cesarean section and possibility of developing type 2 diabetes, as well as for the newborn, such as preterm birth, macrosomia, shoulder dystocia, neonatal hypoglycemia, respiratory distress syndrome and congenital abnormalities [33]. Owing to the strong correlation between GDM and maternal/perinatal/neonatal complications, an early diagnosis is highly recommended. 
In a recent review and meta-analysis, it was shown that risk for perinatal mortality, and neonatal hypoglycemia was greater among early-onset GDM women compared to late-onset GDM women, despite treatment [34].

As a result, screening for GDM should be done as soon as pregnancy is confirmed, especially in high-risk patients, by using fasting plasma glucose cut-off values [35].

The oral glucose tolerance test (OGTT) remains the gold standard for a GDM diagnosis, even though not devoid of limitations, principally associated with patient compliance [36]. One approach, adopted in some countries is a two-step vs one-step testing procedure, although it appears to have similar diagnostic efficiency [37]. Depending on resources, a universal screening of pregnant women has been implemented in some locations while others choose selective screening based on risk factors (age, obesity, obstetric history and ethnicity) [38]. Some serum proteins like insulin, adiponectin, C-reactive protein, sex hormone globulin and glycosylated fibronectin are widely investigated as markers of this pathological condition [39, $40,41]$. Although these results are promising, such predictive biomarkers are yet to achieve clinical applicability.

Advances in molecular biology have recently identified novel biomarkers, which offer the potential to improve GDM risk prediction and, consequently, enable application of intervention protocols. These biomarkers can be readily measured in biological fluids, such as blood, plasma and serum, allowing accurate low-cost diagnosis with improved patient compliance [42]. For example, it was observed that genetic variants, such as single nucleotide polymorphisms (SNPs) in genes involved in specific metabolic pathways may predispose pregnant women to develop GDM [43]. This potentially would allow analysis of a set of SNPs that provide indicators for GDM screening [44].

DNA methylation could also represent an interesting potential parameter correlating with a range of pathophysiological processes, including GDM [45]. Indeed, it was demonstrated that DNA methylation is highly altered in the placenta and cord blood of women with GDM [46]. Micro-RNAs have also proven to be important metabolic regulators during pregnancy, playing a role in GDM onset [47], which would make them ideal candidates for GDM detection. However, establishment of the specificity and sensitivity of potential new biomarkers for GDM diagnosis is required - including external validation and population studies - before they can be used in clinical practice.

\subsection{Why GDM should be treated}

The Hyperglycemia and Adverse Pregnancy Outcome (HAPO) Study evaluated the risk of adverse outcome associated with degrees of glucose intolerance during pregnancy and confirmed the link between maternal glucose and neonatal adiposity and suggested that this relationship is mediated by fetal insulin production influencing fetal growth [48].

Moreover, if not diagnosed and/or untreated, GDM can lead to short-term risks including labor induction, shoulder dystocia, C-section, macrosomia, large for gestational age (LGA) babies, neonatal hypoglycemia, NICU admission [49]. In a lifelong perspective, approximately $40 \%$ of all women who are diagnosed with GDM progress to type 2 diabetes within 5 years post-delivery, in addition to their increased risk of GDM in future pregnancies $[50,51]$.

Noteworthy, infants born to mothers with gestational diabetes are at increased risk of impaired glucose regulation, obesity and diabetes, leading to a vicious cycle of accumulated risks in the next generation [52, 53]. A recent follow-up study reported the longitudinal effects of GDM in the offspring. It included 4.160 children aged 10-14 years, whose mothers had a 75-g OGTT at $\sim 28$ weeks of gestation with blinded glucose values and underwent an OGTT. Offspring exposed to untreated GDM in utero are insulin-resistant with limited $\beta$-cell compensation compared with offspring born to mothers without GDM. GDM is significantly and independently associated with childhood intolerance to glucose [54].

\subsection{Lifestyle changes}

With regards to management, before any therapeutic intervention, the mainstay for GDM approach is based on lifestyle changes with adequate diet and exercise, aiming to achieve glycemic targets. A recent individual patient data meta-analysis reported that such an approach was efficacious in containing gestational weight gain while the impact on GDM diagnoses was reported only for selected populations. No other perinatal outcomes were reported as significantly affected by lifestyle changes [55]. This was mainly 
due to the heterogeneity of approach in the primary trials which included different diets and physical activity programs. Moreover, adherence to lifestyle changes is generally poor and it is inversely correlated with efficacy, namely on GDM onset [56]. Anyway, if glycemic targets are not met, then insulin treatment should be considered without delay, which may also improve the woman's health-related quality of life [57]. Indeed, insulin treatment is associated with less risk of neonatal hypoglycemia and provides a good plasma glucose control [58].

\subsection{Insulin sensitizers}

Earlier observational studies $[59,60,61]$ suggested that metformin treatment was associated with a lower risk of GDM, although the designs of these studies appear prone to different sorts of bias. Indeed, the above findings were not confirmed in a trial of 274 pregnancies among 257 women with PCOS who were randomly assigned to receive metformin $(2000 \mathrm{mg} /$ day) or placebo from the first trimester until delivery. The patients treated with metformin (17.6\%) and placebo (16.9\%) presented a very similar prevalence of GDM. No significant differences were observed in the prevalence of preeclampsia or preterm delivery [62]. Two further trials investigated metformin for the prevention of large for gestational age babies. They included a total of $>800$ pregnant obese mothers (BMI $>30$ ) who received $1500 \mathrm{mg}$ (till $2500 \mathrm{mg}$ ) oral metformin daily (or placebo), starting early in the second trimester. No efficacy of intervention was reported on birthweight and the rate of GDM was similar in metformin- and placebo-treated groups [63, 64]. Interestingly, a reduction of preeclampsia was reported with metformin (3.0\%) in respect with placebo (11.3\%) [63].

On the other hand, several clinical trials demonstrated the significant efficacy of inositols, especially MI, in GDM management (Table 1). Indeed, the concomitant administration of $\mathrm{MI}$ and $\mathrm{DCl}$ seems to perform less well than $\mathrm{MI}$ alone. When the two stereoisomers were directly compared, the non-inferiority analysis demonstrated the largest benefit for women treated with $\mathrm{MI}$ alone compared to those who received $\mathrm{MI}$ plus $\mathrm{DCl}$ or $\mathrm{DCl}$ alone [65]. This effect can also be explained referring to the competition between $\mathrm{MI}$ and $\mathrm{DCl}$ at the transporter site in the intestine. Indeed, SMIT2 in human cells exerts a similar affinity for both compounds with a $\mathrm{Km}$ value between 100 and $160 \mu \mathrm{M}$, depending on the cell model used to determine it [13]. An in vivo pharmacokinetic study demonstrated the DCl inhibitory effect on MI bioavailability [66]. Obviously, a significant increase of $\mathrm{DCl}$ concentration in the gut, due to exogenous administration, hinders MI absorption with consequences on its bioavailability and, implicitly, its efficacy.

A recent systematic review and meta-analysis supported the prophylactic treatment with $\mathrm{Ml}$ in the prevention of GDM. Among the included studies, all but one administered MI alone $(2 \mathrm{~g}$ MI plus $200 \mu \mathrm{g}$ folic acid, twice daily), while another one used a combination of lower MI dose $(1100 \mathrm{mg})$ plus $27.6 \mathrm{mg} \mathrm{DCl} /$ day. The findings demonstrate that the administration of $2 \mathrm{~g}$ Ml twice daily was associated with improved glycemic homeostasis, reduced GDM and preterm delivery rate, in respect to control groups, all supplemented with folic acid, except one trial [30].

Moreover, a secondary analysis from three trials reported that the same dose of $\mathrm{MI}$ supplementation in women at risk for GDM affected birthweight, reducing the rate of both macrosomic newborns and LGA babies [67]. Such neonatal impact agrees with the evidence that dietary glycemic index directly correlates with LGA in newborns [68] and indirectly demonstrate that MI supplementation improves glycemic control in those pregnancies.

Finally, in a condition where insulin-resistance is pathogenetic like PCOS, the beneficial effects of $\mathrm{MI}$ supplementation on hormonal and reproductive disturbances [20] were specifically reported also in pregnancy, where GDM rate was reduced [69].

From the experimental point of view, recent animal studies showed that combined inositols treatment ( $\mathrm{MI} / \mathrm{DCl} 40: 1$ ) in pregnant mouse complicated by metabolic syndrome and obesity improved blood pressure, glucose levels at the glucose tolerance, as well as leptin levels [70]. In addition, the same combination of inositols treatment improved not only maternal outcomes, but also offspring weight at birth as well as glucose tolerance test, and vascular reactivity in their adult life, thus reducing the vicious cycle of dysmetabolism [71].

Finally, it should be highlighted that inositols administration in pregnancy was well tolerated and found to be safe, unlike metformin which has been associated with several gastrointestinal symptoms [63]. 


\section{Prevention of NTDs: the role of MI}

\subsection{Background to NTDs}

Neural tube defects (NTDs) are a group of congenital malformations affecting the brain and spinal cord that originate at various times during gestation. Some authors use the term 'NTDs' to denote defects that specifically result from faulty neural tube closure, particularly myelomeningocele (i.e. open spina bifida) and anencephaly. However, NTDs are sometimes considered to also include defects that arise by other embryonic and fetal mechanisms, including encephalocele (a brain herniation defect) and skin-covered low spinal 'dysraphic' conditions (secondary neurulation defects) [81]. Hydrocephalus and Chiari II malformation are closely associated with myelomeningocele and so are frequently present in individuals with NTDs.

Many different factors affect susceptibility to NTDs, including genetic variants and environmental influences, including the antiepileptic drugs valproic acid and carbamazepine [81]. Nutritional status is important, with folate and vitamin B12 levels in maternal blood being independent risk factors for NTDs [82]. When taken together with the findings of the randomized controlled trial of vitamin usage in NTD prevention [83], this evidence has led to the recommendation that all women planning a pregnancy should take folic acid (FA)-containing supplements to minimize the risk of NTDs [84]. Moreover, many countries now mandate addition of FA to staple foods, to counteract folate deficiency on a population-wide basis, and so enhance NTD prevention [85].

\subsection{Obesity and diabetes as risk factors for NTDs}

Maternal obesity and poorly-controlled diabetes mellitus during pregnancy are established risk factors for NTDs $[86,87]$, although the complexity of the diabetic milieu has made it difficult to pinpoint the precise mechanism(s) by which the diabetic state enhances NTD risk.

The polyol pathway became of attention in the last century. Aldose reductase, key enzyme in this pathway, converts glucose to sorbitol, which is further processed to fructose. Under normal conditions, this enzyme has a low affinity for glucose, and it processes small amount of substrate. However, in diabetes mellitus, the hyperglycemia in some cells causes a marked production of sorbitol with a concomitant reduction of MI concentration.

The depletion of MI has long been thought to be the underlying defect responsible for decreased nerve conduction velocity in experimental diabetes, leading to increased embryo malformations, such as neural tube defects.

Therefore, the potential of aldose reductase inhibitors has been investigated, with the aim to restore MI tissue content. However, treatment with aldose reductase inhibitors failed to correct MI reduction, did not prevent malformations in the embryos and was found associated with significant side effects $[88,89,90]$. The failure of aldose reductase inhibitors to prevent diabetic malformations suggested that the polyol pathway was not involved; in contrast, supplementation with MI restored MI tissue content and reduced the incidence of neural tube defects, suggesting the involvement of $\mathrm{MI}$ in the mechanism of diabetic embryopathy [91, 92].

While hyperglycemia alone is sufficient to cause NTDs in cultured rodent embryos [93], other features of the diabetic environment, including the ketone $\beta$-hydroxybutyrate, can also produce NTDs [94].

The effects of the diabetic milieu on the developing rodent neural tube include intracellular oxidative stress and neuroepithelial cell apoptosis, with many studies showing that antioxidant treatment can protect against these effects $[95,96]$. Nevertheless, precisely how such effects lead to NTDs is unclear. One possibility is a reduction in cellular expression of genes that are vital for neural tube closure, either as a result of cell death or down-regulation of gene expression. For example, Pax3 loss of function causes both cranial and spinal NTDs [97], and some studies have identified disruption of Pax3 expression in mouse embryos of diabetic mothers [98].

In humans, hyperinsulinemia has been suggested as a possible mechanism leading to elevated NTD risk in obese mothers who often have type II diabetes [99]. Even in the absence of diabetes, NTDs have been significantly associated with maternal periconceptional increased intake of simple sugars and a high 
glycemic index, as well as with features of the 'metabolic syndrome' [100, 101, 102]. Hence, there is plentiful evidence linking dysregulation of glucose metabolism, in both types 1 and 2 diabetes, with NTDs.

\subsection{Inositols and NTDs: evidence from animal models}

Diabetic tissues tend to be inositol-deficient, in conjunction with elevated glucose levels [103], and rat embryos cultured under hyperglycemic conditions exhibit diminished MI levels [90]. At neurulation stages, MI deficiency but not other 'vitamin' deficiencies leads to failure of cranial NTDs in cultured rat embryos [104]. Hence, inositol is essential for the neural tube closure process. In terms of prevention, MI supplementation can diminish the frequency of NTDs resulting from hyperglycemic conditions in rats, both in vivo and in embryo culture $[105,106]$.

Perhaps of most relevance to human NTDs, inositol can reduce the frequency of NTDs in a mouse genetic NTD model [107]. A multifactorial etiology underlies most human NTDs, with genetic predisposing variants interacting with environmental factors. In the curly tail mouse, a hypomorphic allele of the $\mathrm{Grh} / 3$ gene is the major genetic change, with 'modifier' genetic variants and various environmental influences affecting frequency and severity of NTDs $[108,109]$. Importantly, NTDs in the curly tail strain are FA-resistant, therefore mimicking FA non-responsive human NTDs. Both $\mathrm{MI}$ and $\mathrm{DCl}$ are preventive in the curly tail model, an effect that is dependent on specific isoforms of protein kinase $C[110,111]$. This preventive action of $\mathrm{MI}$ in the curly tail strain has been replicated in an independent laboratory [112]. Furthermore, in a related strain in which cranial NTDs were inducible by folate deficiency, these defects were prevented by maternal MI supplementation [113]. These findings suggest potential overlap in response to FA and MI for some NTDs.

\subsection{Inositols and NTDs: evidence from human studies}

Diminished MI concentrations have been detected in the plasma of pregnant Dutch women with NTDaffected fetuses. The odds ratio for NTD risk associated with extremely low maternal MI concentration (10$13.2 \mathrm{microM} / \mathrm{L})$ was 2.6 (95\% Cl, 1.1-6.0) [114]. Moreover, a genetic connection between inositol metabolism and NTDs was suggested by findings that cranial NTDs arise in mice with loss of function of Itpk1, encoding inositol 1,3,4-trisphosphate 5/6-kinase which produces the highly phosphorylated metabolite, inositol hexakisphosphate (IP6) [115]. A subsequent study in a high-risk area of China found an association of a maternal polymorphism of ITPK1 increased risk of NTD pregnancy [116].

\subsection{Inositol in the prevention of human NTDs}

Population-wide supplementation with FA through food fortification has significantly reduced the prevalence of NTDs in many countries [85]. However, FA is only partially effective, and NTD cases continue to occur worldwide, with or without voluntary or mandatory FA consumption. Hence, additional strategies are needed to achieve further prevention.

Building on the data from animal models, an inositol supplementation study was conducted in Italy, among high-risk women who had experienced 1 or 2 previous NTD-affected pregnancies. In their next pregnancy, the women took 500-1000 mg/day MI plus $5 \mathrm{mg} /$ day FA, from 2 months pre-conception, until 60 days of pregnancy. No NTD recurrences were observed among 29 pregnancies of 27 women, whereas 2-8 recurrent NTDs would be expected, based on typical population recurrence frequencies [117]. Most of the women were likely folate-resistant, having undergone appropriate peri-conceptional folate intake in their previous NTD-affected pregnancies. Hence, these findings support a preventive effect of MI on NTD recurrence in high-risk pregnancies.

A phase I/II double-blind, case-control clinical trial (the PONTI study; EudraCT2006-000157-22) was performed to gain further experience of $\mathrm{MI}$ supplementation in human pregnancy [118]. The subjects were UK women with a previous NTD pregnancy who planned to become pregnant again. Of 117 women contacted, 99 proved eligible, and 61 undertook a detailed screening questionnaire of whom 47 ( $77 \%$ of those screened) agreed to be randomized to periconceptional supplementation with MI ( $1 \mathrm{~g} /$ day) plus FA (5 $\mathrm{mg} /$ day), or placebo plus FA. Of 33 randomized pregnancies, there was one NTD recurrence in the placebo plus FA group ( $n=19)$ and no recurrences in MI plus FA group ( $n=14)$. Of 52 women who declined randomization, the periconceptional supplementation regime and outcomes of 22 further pregnancies were documented. Two NTDs recurred in women who took only FA in their next pregnancy $(n=3)$, whereas 
there were no recurrences in women who took MI plus FA in their next pregnancy $(n=19)$. Overall, NTDs recurred among 0/33 Ml-supplemented pregnancies and 3/22 FA-only pregnancies ( $p=0.06$, Fisher's Exact test).

Combining data from the Italian and PONTI studies, with post-PONTI experience of MI use, a total of 76 women at high risk of NTDs (52 with one and 24 with two or more previous affected pregnancies) have taken MI plus FA in a subsequent pregnancy, with no recurrences. Assuming a $3 \%$ recurrence risk after one NTD pregnancy and 10\% after two [119], as used in genetic counselling, this indicates that 4 recurrences would be expected among 76 pregnancies. The observed 0/76 recurrences among MI-supplemented pregnancies are significantly different from this expectation (Single Proportion Fisher's Exact, $p=0.016$ ). These observations, although on small patient numbers are encouraging that $\mathrm{MI}$ may have value in increasing NTD prevention beyond that achievable by FA alone.

\subsection{Inositol and NTD prevention: next steps}

A definitive answer to the question of the efficacy of $\mathrm{MI}$ in enhancing NTD prevention is likely to require a fully powered, randomized clinical trial (RCT). However, this will necessitate large numbers of pregnancies, owing to the relatively low recurrence rate for NTDs. Given the current state of knowledge about inositol and NTD prevention, it is important to consider whether a RCT is ethically acceptable, given that the study design would require withholding inositol supplements from a significant number of pregnancies.

Glasziou et al [120] argue that expensive and time-consuming RCTs may be unnecessary in cases where a novel treatment has an obvious effect (i.e. a large 'signal to noise' ratio). However, for NTDs, the effect of inositol at the population level is likely to be small, as NTD frequency is relatively low $(0.1 \%$ for first occurrence; $2-3 \%$ for recurrence), and any effect of inositol will be additional to FA-mediated prevention. On the other hand, for individual women who exhibit FA-resistance, inositol is currently their only option to increase the likelihood of a normal pregnancy.

Freedman [121] suggested that 'clinical equipoise' should be considered to exist when there is genuine uncertainty within the expert medical community about the preferred treatment. Under such circumstances, an RCT would be ethically justified. In the case of NTDs, MI + FA supplements certainly have not superseded FA-only supplements; worldwide, the great majority of low-risk and high-risk women receive FA only (or no supplement at all). To date very few pregnancies have been supplemented with inositol, and this has been used largely where high-risk women have sought advice from the authors of this article.

We conclude that the Glasziou criterion for avoiding an RCT is not met by MI supplementation for NTDs, and that currently the expert field is in a state of clinical equipoise with regard to use of $\mathrm{MI}$ in addition to FA. Hence, an RCT appears indicated to provide a definitive answer to the efficacy of MI as an adjunct preventive supplement for NTDs.

\section{Conclusions}

Gestational diabetes mellitus (GDM) and congenital abnormalities of fetal central nervous system, such as neural tube defects (NTDs), are strongly correlated to glycemic status of pregnant women.

Before starting a therapeutic intervention to achieve a healthy pregnancy, the principle approach to reach the glycemic targets is based on lifestyle changes by means of an adequate diet and exercise.

When glycemic targets are not addressed, an intervention is reasonable to avoid complications both for the mothers and for the fetus.

A supplementation of MI starting at least one month prior to conception and continued until $36^{\text {th }}$ week of pregnancy is expected to prevent NTDs as well as GDM onset and its related negative perinatal outcomes. As a side effects free molecule at the usually administered doses, MI therefore becomes a candidate for being one of the first tools to be used in pre-conceptional medicine.

\section{Expert opinion}

The data reported in this brief narrative review are highly encouraging over the use of inositols, namely MI, in pregnant women. To date, the controlled studies available in literature are reassuring about its safety and tolerability. Adverse effects in the short-term period have not reported yet, either for mothers or babies, despite the widespread use of these supplements since several years, in many countries. 
Although confirmatory studies will be necessary to elucidate the mechanisms involved [122], there is a general agreement that $\mathrm{MI}$ administered early in pregnancy effectively prevents GDM onset (figure 1 ). Proofs are available for different categories of women at risk, namely overweight, obese, and patients affected by PCOS. In addition, significant reduction of gestational hypertensive disorders, preterm birth and large for gestational age babies suggest a perinatal benefit of MI supplementation. Whether this would apply to low-risk population requires the design of appropriate controlled trials, hopefully comparing different inositols combinations.

To date, although several clinical trials are ongoing, MI supplementation has not yet been inserted in clinical guidelines for GDM prevention/treatment.

For congenital malformations like NTDs, MI can offer a novel means of prevention via peri-conceptional supplementation, particularly in those women whose previous pregnancies have proven resistant to FA supplementation (figure 1).

Thus, given the extensive data documenting the safety of peri-conceptional MI supplementation derived from trials done in Assisted Reproduction, a combination of MI and FA could be recommended for every woman at high risk for NTDs.

Furthermore, it would be interesting to carry out studies to reduce the dose and perhaps improve absorption and bioavailability. Recent research using co-administration of $\mathrm{MI}$ and $\alpha$-LA [26] is an example of how MI usage may be clinically improved. We believe that this association in the next years could conquer a relevant position as insulin-sensitizing treatment for GDM and NTDs prevention, due to both efficacy and absence of side effects.

\section{Funding}

This work was not funded

\section{Declaration of interest}

V Unfer is employee at Lo. Li. Pharma s.r.l., Rome, Italy. F Facchinetti has been a consultant of the same company. The authors have no other relevant affiliations or financial involvement with any organization or entity with a financial interest in or financial conflict with the subject matter or materials discussed in the manuscript. This includes employment, consultancies, honoraria, stock ownership or options, expert testimony, grants or patents received or pending, or royalties.

\section{Reviewer disclosures}

Peer reviewers on this manuscript have no relevant financial or other relationships to disclose. 


\section{References}

1. Rogozinska E, Marlin N, Jackson L, et al. Effects of antenatal diet and physical activity on maternal and fetal outcomes: individual patient data meta-analysis and health economic evaluation. Health Technol Assess. 2017 Aug;21(41):1-158. doi: 10.3310/hta21410. PubMed PMID: 28795682; PubMed Central PMCID: PMCPMC5572115.

2. McGowan CA, McAuliffe FM. The influence of maternal glycaemia and dietary glycaemic index on pregnancy outcome in healthy mothers. Br J Nutr. 2010 Jul;104(2):153-9. doi: 10.1017/S0007114510000425. PubMed PMID: 20307352.

3. Group HSCR, Metzger BE, Lowe LP, et al. Hyperglycemia and adverse pregnancy outcomes. N Engl J Med. 2008 May 8;358(19):1991-2002. doi: 10.1056/NEJMoa0707943. PubMed PMID: 18463375.

4. Safi J, Joyeux L, Chalouhi GE. Periconceptional folate deficiency and implications in neural tube defects. J Pregnancy. 2012;2012:295083. doi: 10.1155/2012/295083. PubMed PMID: 22900183; PubMed Central PMCID: PMCPMC3415073.

5. Werner EF, Froehlich RJ. The Potential Role for Myoinositol in the Prevention of Gestational Diabetes Mellitus. Am J Perinatol. 2016 Nov;33(13):1236-1241. doi: 10.1055/s-0036-1584273. PubMed PMID: 27213831.

6. Noventa M, Vitagliano A, Quaranta M, et al. Preventive and Therapeutic Role of Dietary Inositol Supplementation in Periconceptional Period and During Pregnancy: A Summary of Evidences and Future Applications. Reprod Sci. 2016 Mar;23(3):278-88. doi: 10.1177/1933719115594018. PubMed PMID: 26175275.

7. Pak Y, Huang LC, Lilley KJ, et al. In vivo conversion of [3H]myoinositol to [3H]chiroinositol in rat tissues. J Biol Chem. 1992 Aug 25;267(24):16904-10. PubMed PMID: 1387397.

8. Beemster P, Groenen P, Steegers-Theunissen R. Involvement of inositol in reproduction. Nutr Rev. 2002 Mar;60(3):80-7. doi: 10.1301/00296640260042748. PubMed PMID: 11908744.

9. Wong $\mathrm{YH}$, Kalmbach SJ, Hartman BK, et al. Immunohistochemical staining and enzyme activity measurements show myo-inositol-1-phosphate synthase to be localized in the vasculature of brain. J Neurochem. 1987 May;48(5):1434-42. doi: 10.1111/j.1471-4159.1987.tb05682.x. PubMed PMID: 2435847.

10. Loewus MW, Loewus FA, Brillinger GU, et al. Stereochemistry of the myo-inositol-1-phosphate synthase reaction. J Biol Chem. 1980 Dec 25;255(24):11710-2. PubMed PMID: 7002927.

11. Michell RH. Inositol derivatives: evolution and functions. Nat Rev Mol Cell Biol. 2008 Feb;9(2):15161. doi: 10.1038/nrm2334. PubMed PMID: 18216771.

12. Monastra G, Unfer $\mathrm{V}$, Harrath $\mathrm{AH}$, et al. Combining treatment with myo-inositol and D-chiro-inositol $(40: 1)$ is effective in restoring ovary function and metabolic balance in PCOS patients. Gynecol Endocrinol. 2017 Jan;33(1):1-9. doi: 10.1080/09513590.2016.1247797. PubMed PMID: 27898267.

13. Schneider S. Inositol transport proteins. FEBS Lett. 2015 Apr 28;589(10):1049-58. doi: 10.1016/j.febslet.2015.03.012. PubMed PMID: 25819438.

14. Aouameur R, Da Cal S, Bissonnette $P$, et al. SMIT2 mediates all myo-inositol uptake in apical membranes of rat small intestine. Am J Physiol Gastrointest Liver Physiol. 2007 Dec;293(6):G13007. doi: 10.1152/ajpgi.00422.2007. PubMed PMID: 17932225.

15. Di Paolo G, De Camilli P. Phosphoinositides in cell regulation and membrane dynamics. Nature. 2006 Oct 12;443(7112):651-7. doi: 10.1038/nature05185. PubMed PMID: 17035995.

16. Bizzarri M, Fuso A, Dinicola $S$, et al. Pharmacodynamics and pharmacokinetics of inositol(s) in health and disease. Expert Opin Drug Metab Toxicol. 2016 Oct;12(10):1181-96. doi: 10.1080/17425255.2016.1206887. PubMed PMID: 27351907.

17. Lagana AS, Garzon S, Casarin J, et al. Inositol in Polycystic Ovary Syndrome: Restoring Fertility through a Pathophysiology-Based Approach. Trends Endocrinol Metab. 2018 Nov;29(11):768-780. doi: 10.1016/j.tem.2018.09.001. PubMed PMID: 30270194.

18. Nestler JE, Unfer V. Reflections on inositol(s) for PCOS therapy: steps toward success. Gynecol Endocrinol. 2015 Jul;31(7):501-5. doi: 10.3109/09513590.2015.1054802. PubMed PMID: 26177098.

19. Facchinetti F, Appetecchia M, Aragona C, et al. Experts' opinion on inositols in treating polycystic ovary syndrome and non-insulin dependent diabetes mellitus: a further help for human 
reproduction and beyond. Expert Opin Drug Metab Toxicol. 2020 Mar;16(3):255-274. doi: 10.1080/17425255.2020.1737675. PubMed PMID: 32129111.

20. Unfer V, Nestler JE, Kamenov ZA, et al. Effects of Inositol(s) in Women with PCOS: A Systematic Review of Randomized Controlled Trials. Int J Endocrinol. 2016;2016:1849162. doi: 10.1155/2016/1849162. PubMed PMID: 27843451; PubMed Central PMCID: PMCPMC5097808.

21. Croze ML, Soulage CO. Potential role and therapeutic interests of myo-inositol in metabolic diseases. Biochimie. 2013 Oct;95(10):1811-27. doi: 10.1016/j.biochi.2013.05.011. PubMed PMID: 23764390.

22. Sun TH, Heimark DB, Nguygen T, et al. Both myo-inositol to chiro-inositol epimerase activities and chiro-inositol to myo-inositol ratios are decreased in tissues of GK type 2 diabetic rats compared to Wistar controls. Biochem Biophys Res Commun. 2002 May 10;293(3):1092-8. doi: 10.1016/S0006291X(02)00313-3. PubMed PMID: 12051772.

23. Heimark D, McAllister J, Larner J. Decreased myo-inositol to chiro-inositol (M/C) ratios and increased $\mathrm{M} / \mathrm{C}$ epimerase activity in PCOS theca cells demonstrate increased insulin sensitivity compared to controls. Endocr J. 2014;61(2):111-7. doi: 10.1507/endocrj.ej13-0423. PubMed PMID: 24189751.

24. Chukwuma $\mathrm{Cl}$, Ibrahim MA, Islam MS. Myo-inositol inhibits intestinal glucose absorption and promotes muscle glucose uptake: a dual approach study. J Physiol Biochem. 2016 Dec;72(4):791801. doi: 10.1007/s13105-016-0517-1. PubMed PMID: 27601253.

25. Milewska EM, Czyzyk A, Meczekalski B, et al. Inositol and human reproduction. From cellular metabolism to clinical use. Gynecol Endocrinol. 2016 Sep;32(9):690-695. doi: 10.1080/09513590.2016.1188282. PubMed PMID: 27595157.

26. Monastra G, Sambuy Y, Ferruzza S, et al. Alpha-lactalbumin Effect on Myo-inositol Intestinal Absorption: In vivo and In vitro. Curr Drug Deliv. 2018;15(9):1305-1311. doi: 10.2174/1567201815666180509102641. PubMed PMID: 29745333.

27. Permyakov EA, Berliner LJ. alpha-Lactalbumin: structure and function. FEBS Lett. 2000 May 19;473(3):269-74. doi: 10.1016/s0014-5793(00)01546-5. PubMed PMID: 10818224.

28. Montanino Oliva $\mathrm{M}$, Buonomo $\mathrm{G}$, Calcagno $\mathrm{M}$, et al. Effects of myo-inositol plus alpha-lactalbumin in myo-inositol-resistant PCOS women. J Ovarian Res. 2018 May 10;11(1):38. doi: 10.1186/s13048018-0411-2. PubMed PMID: 29747700; PubMed Central PMCID: PMCPMC5944130.

29. Carlomagno G, Unfer V. Inositol safety: clinical evidences. Eur Rev Med Pharmacol Sci. 2011 Aug;15(8):931-6. PubMed PMID: 21845803.

30. Vitagliano A, Saccone G, Cosmi E, et al. Inositol for the prevention of gestational diabetes: a systematic review and meta-analysis of randomized controlled trials. Arch Gynecol Obstet. 2019 Jan;299(1):55-68. doi: 10.1007/s00404-018-5005-0. PubMed PMID: 30564926.

31. Crawford TJ, Crowther CA, Alsweiler J, et al. Antenatal dietary supplementation with myo-inositol in women during pregnancy for preventing gestational diabetes. Cochrane Database Syst Rev. 2015 Dec 17(12):CD011507. doi: 10.1002/14651858.CD011507.pub2. PubMed PMID: 26678256; PubMed Central PMCID: PMCPMC6599829.

32. Zhu Y, Zhang C. Prevalence of Gestational Diabetes and Risk of Progression to Type 2 Diabetes: a Global Perspective. Curr Diab Rep. 2016 Jan;16(1):7. doi: 10.1007/s11892-015-0699-x. PubMed PMID: 26742932; PubMed Central PMCID: PMCPMC6675405.

33. Chiefari E, Arcidiacono B, Foti D, et al. Gestational diabetes mellitus: an updated overview. J Endocrinol Invest. 2017 Sep;40(9):899-909. doi: 10.1007/s40618-016-0607-5. PubMed PMID: 28283913.

34. Immanuel J, Simmons D. Screening and Treatment for Early-Onset Gestational Diabetes Mellitus: a Systematic Review and Meta-analysis. Curr Diab Rep. 2017 Oct 2;17(11):115. doi: 10.1007/s11892017-0943-7. PubMed PMID: 28971305.

35. Baz B, Riveline JP, Gautier JF. ENDOCRINOLOGY OF PREGNANCY: Gestational diabetes mellitus: definition, aetiological and clinical aspects. Eur J Endocrinol. 2016 Feb;174(2):R43-51. doi: 10.1530/EJE-15-0378. PubMed PMID: 26431552.

36. International Association of D, Pregnancy Study Groups Consensus P, Metzger BE, et al. International association of diabetes and pregnancy study groups recommendations on the 
diagnosis and classification of hyperglycemia in pregnancy. Diabetes Care. 2010 Mar;33(3):676-82. doi: 10.2337/dc09-1848. PubMed PMID: 20190296; PubMed Central PMCID: PMCPMC2827530.

37. Khalifeh A, Eckler R, Felder L, et al. One-step versus two-step diagnostic testing for gestational diabetes: a randomized controlled trial. J Matern Fetal Neonatal Med. 2020 Feb;33(4):612-617. doi: 10.1080/14767058.2018.1498480. PubMed PMID: 29985079.

38. Agarwal MM. Gestational diabetes mellitus: An update on the current international diagnostic criteria. World J Diabetes. 2015 Jun 25;6(6):782-91. doi: 10.4239/wjd.v6.i6.782. PubMed PMID: 26131321; PubMed Central PMCID: PMCPMC4478575.

39. Smirnakis KV, Plati A, Wolf $\mathrm{M}$, et al. Predicting gestational diabetes: choosing the optimal early serum marker. Am J Obstet Gynecol. 2007 Apr;196(4):410 e1-6; discussion 410 e6-7. doi: 10.1016/j.ajog.2006.12.011. PubMed PMID: 17403439.

40. Nanda S, Savvidou M, Syngelaki A, et al. Prediction of gestational diabetes mellitus by maternal factors and biomarkers at 11 to 13 weeks. Prenat Diagn. 2011 Feb;31(2):135-41. doi: 10.1002/pd.2636. PubMed PMID: 21268030.

41. Rasanen JP, Snyder CK, Rao PV, et al. Glycosylated fibronectin as a first-trimester biomarker for prediction of gestational diabetes. Obstet Gynecol. 2013 Sep;122(3):586-94. doi: 10.1097/AOG.0b013e3182a0c88b. PubMed PMID: 23921871.

42. Sahu PP, N.; Dubey, R.D.; Paroha, S.; Chatterjee, S.; Chatterjee, T. . Biomarkers: An emerging tool for diagnosis of a disease and drug development. . Asian J Res Pharm Sci 2011;1:9-16.

43. Wu L, Cui L, Tam WH, et al. Genetic variants associated with gestational diabetes mellitus: a metaanalysis and subgroup analysis. Sci Rep. 2016 Jul 29;6:30539. doi: 10.1038/srep30539. PubMed PMID: 27468700; PubMed Central PMCID: PMCPMC4965817.

44. Dias S, Pheiffer C, Abrahams Y, et al. Molecular Biomarkers for Gestational Diabetes Mellitus. Int J Mol Sci. 2018 Sep 26;19(10). doi: 10.3390/ijms19102926. PubMed PMID: 30261627; PubMed Central PMCID: PMCPMC6213110.

45. Houde AA, Guay SP, Desgagne V, et al. Adaptations of placental and cord blood ABCA1 DNA methylation profile to maternal metabolic status. Epigenetics. 2013 Dec;8(12):1289-302. doi: 10.4161/epi.26554. PubMed PMID: 24113149; PubMed Central PMCID: PMCPMC3933490.

46. Haertle L, El Hajj N, Dittrich M, et al. Epigenetic signatures of gestational diabetes mellitus on cord blood methylation. Clin Epigenetics. 2017;9:28. doi: 10.1186/s13148-017-0329-3. PubMed PMID: 28360945; PubMed Central PMCID: PMCPMC5368916.

47. Wang K, Yuan Y, Cho JH, et al. Comparing the MicroRNA spectrum between serum and plasma. PLoS One. 2012;7(7):e41561. doi: 10.1371/journal.pone.0041561. PubMed PMID: 22859996; PubMed Central PMCID: PMCPMC3409228.

48. Group HSCR. Hyperglycemia and Adverse Pregnancy Outcome (HAPO) Study: associations with neonatal anthropometrics. Diabetes. 2009 Feb;58(2):453-9. doi: 10.2337/db08-1112. PubMed PMID: 19011170; PubMed Central PMCID: PMCPMC2628620.

49. Shah BR, Sharifi F. Perinatal outcomes for untreated women with gestational diabetes by IADPSG criteria: a population-based study. BJOG. 2020 Jan;127(1):116-122. doi: 10.1111/1471-0528.15964. PubMed PMID: 31553136.

50. Bellamy L, Casas JP, Hingorani AD, et al. Type 2 diabetes mellitus after gestational diabetes: a systematic review and meta-analysis. Lancet. 2009 May 23;373(9677):1773-9. doi: 10.1016/S01406736(09)60731-5. PubMed PMID: 19465232.

51. Schwartz N, Nachum Z, Green MS. The prevalence of gestational diabetes mellitus recurrence-effect of ethnicity and parity: a metaanalysis. Am J Obstet Gynecol. 2015 Sep;213(3):310-7. doi: 10.1016/j.ajog.2015.03.011. PubMed PMID: 25757637.

52. Herring SJ, Oken E. Obesity and diabetes in mothers and their children: can we stop the intergenerational cycle? Curr Diab Rep. 2011 Feb;11(1):20-7. doi: 10.1007/s11892-010-0156-9. PubMed PMID: 20963519; PubMed Central PMCID: PMCPMC3191112.

53. Battista MC, Hivert MF, Duval K, et al. Intergenerational cycle of obesity and diabetes: how can we reduce the burdens of these conditions on the health of future generations? Exp Diabetes Res. 2011;2011:596060. doi: 10.1155/2011/596060. PubMed PMID: 22110473; PubMed Central PMCID: PMCPMC3205776. 
54. Lowe WL, Jr., Scholtens DM, Kuang A, et al. Hyperglycemia and Adverse Pregnancy Outcome Follow-up Study (HAPO FUS): Maternal Gestational Diabetes Mellitus and Childhood Glucose Metabolism. Diabetes Care. 2019 Mar;42(3):372-380. doi: 10.2337/dc18-1646. PubMed PMID: 30655380; PubMed Central PMCID: PMCPMC6385693.

55. International Weight Management in Pregnancy Collaborative G. Effect of diet and physical activity based interventions in pregnancy on gestational weight gain and pregnancy outcomes: metaanalysis of individual participant data from randomised trials. BMJ. 2017 Jul 19;358:j3119. doi: 10.1136/bmj.j3119. PubMed PMID: 28724518; PubMed Central PMCID: PMCPMC6887834 at www.icmje.org/coi disclosure.pdf and declare: no support from any organisation for the submitted work. HH reports grants from the German Ministry of Education and Research, the Bavarian Ministry of Agriculture and Nutrition, the Bavarian Ministry of Health, the Helmholtz Center Munich, the Else Kroner-Fresenius Foundation, AOK Bavaria, Amway, and the German Research Foundation outside the submitted work. BWJM reports funding from ObsEva during the conduct of the study.

56. Bruno R, Petrella E, Bertarini V, et al. Adherence to a lifestyle programme in overweight/obese pregnant women and effect on gestational diabetes mellitus: a randomized controlled trial. Matern Child Nutr. 2017 Jul;13(3). doi: 10.1111/mcn.12333. PubMed PMID: 27647837; PubMed Central PMCID: PMCPMC6866030.

57. Crowther CA, Hiller JE, Moss JR, et al. Effect of treatment of gestational diabetes mellitus on pregnancy outcomes. N Engl J Med. 2005 Jun 16;352(24):2477-86. doi: 10.1056/NEJMoa042973. PubMed PMID: 15951574.

58. Simeonova-Krstevska S, Bogoev M, Bogoeva K, et al. Maternal and Neonatal Outcomes in Pregnant Women with Gestational Diabetes Mellitus Treated with Diet, Metformin or Insulin. Open Access Maced J Med Sci. 2018 May 20;6(5):803-807. doi: 10.3889/oamjms.2018.200. PubMed PMID: 29875849; PubMed Central PMCID: PMCPMC5985864.

59. Begum MR, Khanam NN, Quadir E, et al. Prevention of gestational diabetes mellitus by continuing metformin therapy throughout pregnancy in women with polycystic ovary syndrome. J Obstet Gynaecol Res. 2009 Apr;35(2):282-6. doi: 10.1111/j.1447-0756.2008.00876.x. PubMed PMID: 19708174.

60. Glueck CJ, Goldenberg N, Wang P, et al. Metformin during pregnancy reduces insulin, insulin resistance, insulin secretion, weight, testosterone and development of gestational diabetes: prospective longitudinal assessment of women with polycystic ovary syndrome from preconception throughout pregnancy. Hum Reprod. 2004 Mar;19(3):510-21. doi: 10.1093/humrep/deh109. PubMed PMID: 14998944.

61. Glueck CJ, Pranikoff J, Aregawi D, et al. Prevention of gestational diabetes by metformin plus diet in patients with polycystic ovary syndrome. Fertil Steril. 2008 Mar;89(3):625-34. doi: 10.1016/j.fertnstert.2007.03.036. PubMed PMID: 17678910.

62. Vanky E, Stridsklev S, Heimstad R, et al. Metformin versus placebo from first trimester to delivery in polycystic ovary syndrome: a randomized, controlled multicenter study. J Clin Endocrinol Metab. 2010 Dec;95(12):E448-55. doi: 10.1210/jc.2010-0853. PubMed PMID: 20926533.

63. Syngelaki A, Nicolaides KH, Balani J, et al. Metformin versus Placebo in Obese Pregnant Women without Diabetes Mellitus. N Engl J Med. 2016 Feb 4;374(5):434-43. doi: 10.1056/NEJMoa1509819. PubMed PMID: 26840133.

64. Chiswick C, Reynolds RM, Denison F, et al. Effect of metformin on maternal and fetal outcomes in obese pregnant women (EMPOWaR): a randomised, double-blind, placebo-controlled trial. Lancet Diabetes Endocrinol. 2015 Oct;3(10):778-86. doi: 10.1016/S2213-8587(15)00219-3. PubMed PMID: 26165398; PubMed Central PMCID: PMCPMC4673088.

65. Celentano C, Matarrelli B, Pavone G, et al. The influence of different inositol stereoisomers supplementation in pregnancy on maternal gestational diabetes mellitus and fetal outcomes in high-risk patients: a randomized controlled trial. J Matern Fetal Neonatal Med. 2020 Mar;33(5):743-751. doi: 10.1080/14767058.2018.1500545. PubMed PMID: 30558466. 
66. Garzon S, Lagana AS, Monastra G. Risk of reduced intestinal absorption of myo-inositol caused by D-chiro-inositol or by glucose transporter inhibitors. Expert Opin Drug Metab Toxicol. 2019 Aug 8:17. doi: 10.1080/17425255.2019.1651839. PubMed PMID: 31382802.

67. Santamaria A, Alibrandi A, Di Benedetto A, et al. Clinical and metabolic outcomes in pregnant women at risk for gestational diabetes mellitus supplemented with myo-inositol: a secondary analysis from 3 RCTs. Am J Obstet Gynecol. 2018 Sep;219(3):300 e1-300 e6. doi:

10.1016/j.ajog.2018.05.018. PubMed PMID: 29859136.

68. Facchinetti F VV, Petrella Elisabetta, Gambigliani Zoccoli Sofia, Pignatti Lucrezia, Di Cerbo Lidia, Neri Elisabetta. Food glycemic index changes in overweight/obese pregnant women enrolled in a lifestyle program: a randomized controlled trial AJOG MFM 2019;1 (3):100030

69. D'Anna R, Di Benedetto V, Rizzo P, et al. Myo-inositol may prevent gestational diabetes in PCOS women. Gynecol Endocrinol. 2012 Jun;28(6):440-2. doi: 10.3109/09513590.2011.633665. PubMed PMID: 22122627.

70. Ferrari $F$, Facchinetti $F$, Ontiveros $A E$, et al. The effect of combined inositol supplementation on maternal metabolic profile in pregnancies complicated by metabolic syndrome and obesity. Am J Obstet Gynecol. 2016 Oct;215(4):503 e1-8. doi: 10.1016/j.ajog.2016.05.038. PubMed PMID: 27255472.

71. Longo $\mathrm{M}$, Alrais $\mathrm{M}$, Tamayo $\mathrm{EH}$, et al. Vascular and metabolic profiles in offspring born to pregnant mice with metabolic syndrome treated with inositols. Am J Obstet Gynecol. 2019 Mar;220(3):279 e1-279 e9. doi: 10.1016/j.ajog.2018.11.1101. PubMed PMID: 30521799.

72. Matarrelli B, Vitacolonna E, D'Angelo $M$, et al. Effect of dietary myo-inositol supplementation in pregnancy on the incidence of maternal gestational diabetes mellitus and fetal outcomes: a randomized controlled trial. J Matern Fetal Neonatal Med. 2013 Jul;26(10):967-72. doi: 10.3109/14767058.2013.766691. PubMed PMID: 23327487.

73. D'Anna R, Scilipoti A, Giordano D, et al. myo-Inositol supplementation and onset of gestational diabetes mellitus in pregnant women with a family history of type 2 diabetes: a prospective, randomized, placebo-controlled study. Diabetes Care. 2013 Apr;36(4):854-7. doi: 10.2337/dc121371. PubMed PMID: 23340885; PubMed Central PMCID: PMCPMC3609506.

74. Malvasi A, Casciaro F, Minervini MM, et al. Myo-inositol, D-chiro-inositol, folic acid and manganese in second trimester of pregnancy: a preliminary investigation. Eur Rev Med Pharmacol Sci. 2014;18(2):270-4. PubMed PMID: 24488919.

75. D'Anna R, Di Benedetto A, Scilipoti A, et al. Myo-inositol Supplementation for Prevention of Gestational Diabetes in Obese Pregnant Women: A Randomized Controlled Trial. Obstet Gynecol. 2015 Aug;126(2):310-5. doi: 10.1097/AOG.0000000000000958. PubMed PMID: 26241420.

76. Santamaria A, Di Benedetto A, Petrella E, et al. Myo-inositol may prevent gestational diabetes onset in overweight women: a randomized, controlled trial. J Matern Fetal Neonatal Med. 2016 Oct;29(19):3234-7. doi: 10.3109/14767058.2015.1121478. PubMed PMID: 26698911.

77. Lubin V, Shojai R, Darmon P, et al. A pilot study of gestational diabetes mellitus not controlled by diet alone: First-line medical treatment with myoinositol may limit the need for insulin. Diabetes Metab. 2016 Jun;42(3):192-5. doi: 10.1016/j.diabet.2016.01.005. PubMed PMID: 26948394.

78. Farren M, Daly N, McKeating A, et al. The Prevention of Gestational Diabetes Mellitus With Antenatal Oral Inositol Supplementation: A Randomized Controlled Trial. Diabetes Care. 2017 Jun;40(6):759-763. doi: 10.2337/dc16-2449. PubMed PMID: 28325784.

79. Fraticelli F, Celentano C, Zecca IA, et al. Effect of inositol stereoisomers at different dosages in gestational diabetes: an open-label, parallel, randomized controlled trial. Acta Diabetol. 2018 Aug;55(8):805-812. doi: 10.1007/s00592-018-1157-4. PubMed PMID: 29774465.

80. Pintaudi B, Di Vieste G, Corrado F, et al. Effects of myo-inositol on glucose variability in women with gestational diabetes. Eur Rev Med Pharmacol Sci. 2018 Oct;22(19):6567-6572. doi: 10.26355/eurrev_201810_16073. PubMed PMID: 30338829.

81. Copp AJ, Stanier P, Greene ND. Neural tube defects: recent advances, unsolved questions, and controversies. Lancet Neurol. 2013 Aug;12(8):799-810. doi: 10.1016/S1474-4422(13)70110-8. PubMed PMID: 23790957; PubMed Central PMCID: PMCPMC4023229. 
82. Kirke PN, Molloy AM, Daly LE, et al. Maternal plasma folate and vitamin B12 are independent risk factors for neural tube defects. Q J Med. 1993 Nov;86(11):703-8. PubMed PMID: 8265769.

83. Prevention of neural tube defects: results of the Medical Research Council Vitamin Study. MRC Vitamin Study Research Group. Lancet. 1991 Jul 20;338(8760):131-7. PubMed PMID: 1677062.

84. Oakley GP, Jr., Bell KN, Weber MB. Recommendations for accelerating global action to prevent folic acid-preventable birth defects and other folate-deficiency diseases: meeting of experts on preventing folic acid-preventable neural tube defects. Birth Defects Res A Clin Mol Teratol. 2004 Nov;70(11):835-7. doi: 10.1002/bdra.20058. PubMed PMID: 15390317.

85. Kancherla V, Wagh K, Johnson Q, et al. A 2017 global update on folic acid-preventable spina bifida and anencephaly. Birth Defects Res. 2018 Aug 15;110(14):1139-1147. doi: 10.1002/bdr2.1366. PubMed PMID: 30070772.

86. Rasmussen SA, Chu SY, Kim SY, et al. Maternal obesity and risk of neural tube defects: a metaanalysis. Am J Obstet Gynecol. 2008 Jun;198(6):611-9. doi: 10.1016/j.ajog.2008.04.021. PubMed PMID: 18538144.

87. Kucera J. Rate and type of congenital anomalies among offspring of diabetic women.J Reprod Med. 1971 Aug;7(2):73-82. PubMed PMID: 5095696.

88. Eriksson UJ, Naeser P, Brolin SE. Increased accumulation of sorbitol in offspring of manifest diabetic rats. Diabetes. 1986 Dec;35(12):1356-63. doi: 10.2337/diab.35.12.1356. PubMed PMID: 3770312.

89. Eriksson UJ, Brolin SE, Naeser P. Influence of sorbitol accumulation on growth and development of embryos cultured in elevated levels of glucose and fructose. Diabetes Res. 1989 May;11(1):27-32. PubMed PMID: 2515932.

90. Hod M, Star S, Passonneau JV, et al. Effect of hyperglycemia on sorbitol and myo-inositol content of cultured rat conceptus: failure of aldose reductase inhibitors to modify myo-inositol depletion and dysmorphogenesis. Biochem Biophys Res Commun. 1986 Nov 14;140(3):974-80. doi: 10.1016/0006291x(86)90731-x. PubMed PMID: 3096334.

91. Hod M, Star S, Passonneau J, et al. Glucose-induced dysmorphogenesis in the cultured rat conceptus: prevention by supplementation with myo-inositol. Isr J Med Sci. 1990 Oct;26(10):541-4. PubMed PMID: 2249926.

92. Zabihi S, Loeken MR. Understanding diabetic teratogenesis: where are we now and where are we going? Birth Defects Res A Clin Mol Teratol. 2010 Oct;88(10):779-90. doi: 10.1002/bdra.20704. PubMed PMID: 20706996; PubMed Central PMCID: PMCPMC5070114.

93. Cockroft DL, Coppola PT. Teratogenic effects of excess glucose on head-fold rat embryos in culture. Teratology. 1977 Oct;16(2):141-6. doi: 10.1002/tera.1420160205. PubMed PMID: 412267.

94. Hunter ES, 3rd, Sadler TW. D-(-)-beta-hydroxybutyrate-induced effects on mouse embryos in vitro. Teratology. 1987 Oct;36(2):259-64. doi: 10.1002/tera.1420360214. PubMed PMID: 3424210.

95. Reece EA, WU YK. Prevention of diabetic embryopathy in offspring of diabetic rats with use of a cocktail of deficient substrates and an antioxidant. Am J Obstet Gynecol. 1997 Apr;176(4):790-7; discussion 797-8. doi: 10.1016/s0002-9378(97)70602-1. PubMed PMID: 9125602.

96. Zhong J, Xu C, Gabbay-Benziv R, et al. Superoxide dismutase 2 overexpression alleviates maternal diabetes-induced neural tube defects, restores mitochondrial function and suppresses cellular stress in diabetic embryopathy. Free Radic Biol Med. 2016 Jul;96:234-44. doi: 10.1016/j.freeradbiomed.2016.04.030. PubMed PMID: 27130031; PubMed Central PMCID: PMCPMC4912469.

97. Greene ND, Massa V, Copp AJ. Understanding the causes and prevention of neural tube defects: Insights from the splotch mouse model. Birth Defects Res A Clin Mol Teratol. 2009 Apr;85(4):32230. doi: 10.1002/bdra.20539. PubMed PMID: 19180568.

98. Fine $\mathrm{EL}, \mathrm{Horal} \mathrm{M}$, Chang $\mathrm{TI}$, et al. Evidence that elevated glucose causes altered gene expression, apoptosis, and neural tube defects in a mouse model of diabetic pregnancy. Diabetes. 1999 Dec;48(12):2454-62. doi: 10.2337/diabetes.48.12.2454. PubMed PMID: 10580436.

99. Hendricks KA, Nuno OM, Suarez $L$, et al. Effects of hyperinsulinemia and obesity on risk of neural tube defects among Mexican Americans. Epidemiology. 2001 Nov;12(6):630-5. doi: 10.1097/00001648-200111000-00009. PubMed PMID: 11679789. 
100. Shaw GM, Quach T, Nelson V, et al. Neural tube defects associated with maternal periconceptional dietary intake of simple sugars and glycemic index. Am J Clin Nutr. 2003 Nov;78(5):972-8. doi: 10.1093/ajcn/78.5.972. PubMed PMID: 14594784.

101. Yazdy MM, Liu S, Mitchell AA, et al. Maternal dietary glycemic intake and the risk of neural tube defects. Am J Epidemiol. 2010 Feb 15;171(4):407-14. doi: 10.1093/aje/kwp395. PubMed PMID: 20042435; PubMed Central PMCID: PMCPMC2842193.

102. Ray JG, Thompson MD, Vermeulen MJ, et al. Metabolic syndrome features and risk of neural tube defects. BMC Pregnancy Childbirth. 2007 Sep 19;7:21. doi: 10.1186/1471-2393-7-21. PubMed PMID: 17880716; PubMed Central PMCID: PMCPMC2039731.

103. Greene DA. Sorbitol, myo-inositol and sodium-potassium ATPase in diabetic peripheral nerve. Drugs. 1986;32 Suppl 2:6-14. doi: 10.2165/00003495-198600322-00004. PubMed PMID: 3024950.

104. Cockroft DL, Brook FA, Copp AJ. Inositol deficiency increases the susceptibility to neural tube defects of genetically predisposed (curly tail) mouse embryos in vitro. Teratology. 1992 Feb;45(2):223-32. doi: 10.1002/tera.1420450216. PubMed PMID: 1615432.

105. Baker L, Piddington R, Goldman A, et al. Myo-inositol and prostaglandins reverse the glucose inhibition of neural tube fusion in cultured mouse embryos. Diabetologia. 1990 Oct;33(10):593-6. doi: 10.1007/bf00400202. PubMed PMID: 2257996.

106. Khandelwal M, Reece EA, Wu YK, et al. Dietary myo-inositol therapy in hyperglycemia-induced embryopathy. Teratology. 1998 Feb;57(2):79-84. doi: 10.1002/(SICI)10969926(199802)57:2<79::AID-TERA6>3.0.CO;2-1. PubMed PMID: 9562680.

107. Greene ND, Copp AJ. Inositol prevents folate-resistant neural tube defects in the mouse. Nat Med. 1997 Jan;3(1):60-6. doi: 10.1038/nm0197-60. PubMed PMID: 8986742.

108. Gustavsson P, Copp AJ, Greene ND. Grainyhead genes and mammalian neural tube closure. Birth Defects Res A Clin Mol Teratol. 2008 Oct;82(10):728-35. doi: 10.1002/bdra.20494. PubMed PMID: 18683893.

109. De Castro SC, Malhas A, Leung KY, et al. Lamin b1 polymorphism influences morphology of the nuclear envelope, cell cycle progression, and risk of neural tube defects in mice. PLoS Genet. 2012;8(11):e1003059. doi: 10.1371/journal.pgen.1003059. PubMed PMID: 23166514; PubMed Central PMCID: PMCPMC3499363.

110. Cogram P, Tesh S, Tesh J, et al. D-chiro-inositol is more effective than myo-inositol in preventing folate-resistant mouse neural tube defects. Hum Reprod. 2002 Sep;17(9):2451-8. doi: 10.1093/humrep/17.9.2451. PubMed PMID: 12202440.

111. Cogram $P$, Hynes $A$, Dunlevy $L P$, et al. Specific isoforms of protein kinase $C$ are essential for prevention of folate-resistant neural tube defects by inositol. Hum Mol Genet. 2004 Jan 1;13(1):714. doi: $10.1093 / \mathrm{hmg} /$ ddh003. PubMed PMID: 14613966.

112. Ting SB, Wilanowski $\mathrm{T}$, Auden $\mathrm{A}$, et al. Inositol- and folate-resistant neural tube defects in mice lacking the epithelial-specific factor Grhl-3. Nat Med. 2003 Dec;9(12):1513-9. doi: 10.1038/nm961. PubMed PMID: 14608380.

113. Burren KA, Scott JM, Copp AJ, et al. The genetic background of the curly tail strain confers susceptibility to folate-deficiency-induced exencephaly. Birth Defects Res A Clin Mol Teratol. 2010 Feb;88(2):76-83. doi: 10.1002/bdra.20632. PubMed PMID: 19824061; PubMed Central PMCID: PMCPMC3071937.

114. Groenen PM, Peer PG, Wevers RA, et al. Maternal myo-inositol, glucose, and zinc status is associated with the risk of offspring with spina bifida. Am J Obstet Gynecol. 2003 Dec;189(6):17139. doi: 10.1016/s0002-9378(03)00807-x. PubMed PMID: 14710103.

115. Wilson MP, Hugge $C$, Bielinska $M$, et al. Neural tube defects in mice with reduced levels of inositol 1,3,4-trisphosphate 5/6-kinase. Proc Natl Acad Sci U S A. 2009 Jun 16;106(24):9831-5. doi: 10.1073/pnas.0904172106. PubMed PMID: 19482943; PubMed Central PMCID: PMCPMC2701051.

116. Guan Z, Wang J, Guo J, et al. The maternal ITPK1 gene polymorphism is associated with neural tube defects in a high-risk Chinese population. PLoS One. 2014;9(1):e86145. doi: 10.1371/journal.pone.0086145. PubMed PMID: 24465924; PubMed Central PMCID: PMCPMC3896452. eng. 
117. Cavalli P, Ronda E. Myoinositol: The Bridge (PONTI) to Reach a Healthy Pregnancy. Int J Endocrinol. 2017;2017:5846286. doi: 10.1155/2017/5846286. PubMed PMID: 28243254; PubMed Central PMCID: PMCPMC5274721.

118. Greene ND, Leung KY, Gay V, et al. Inositol for the prevention of neural tube defects: a pilot randomised controlled trial. Br J Nutr. 2016 Mar 28;115(6):974-83. doi:

10.1017/S0007114515005322. PubMed PMID: 26847388; PubMed Central PMCID: PMCPMC4825100.

119. Firth. H.V. and Hurst JA. Clinical Genetics and Genomics (Oxford Desk Ref) 2nd Edition. Oxford: Oxford University Press; 2017.

120. Glasziou $P$, Chalmers I, Rawlins $M$, et al. When are randomised trials unnecessary? Picking signal from noise. BMJ. 2007 Feb 17;334(7589):349-51. doi: 10.1136/bmj.39070.527986.68. PubMed PMID: 17303884; PubMed Central PMCID: PMCPMC1800999.

121. Freedman B. Equipoise and the ethics of clinical research. N Engl J Med. 1987 Jul 16;317(3):141-5. doi: 10.1056/NEJM198707163170304. PubMed PMID: 3600702.

122. Agha-Jaffar R, Oliver N, Johnston D, et al. Gestational diabetes mellitus: does an effective prevention strategy exist? Nat Rev Endocrinol. 2016 Sep;12(9):533-46. doi: 10.1038/nrendo.2016.88. PubMed PMID: 27339886. 


\section{Figure legends}

Figure 1. Schematic representation of the effectiveness of MI supplementation in preventing GDM and NTDs.

Table 1. Clinical trials investigating the effects of inositols supplementation in pregnant women.

\begin{tabular}{|c|c|c|c|c|c|}
\hline Study & Population & $\begin{array}{l}\text { Active } \\
\text { Intervention }\end{array}$ & Main outcome & $\begin{array}{l}\text { Delivery } \\
\text { outcomes }\end{array}$ & $\begin{array}{l}\text { Perinatal } \\
\text { outcomes }\end{array}$ \\
\hline $\begin{array}{l}\text { Matarrelli } \\
\text { et al } 2013 \\
{[72]}\end{array}$ & $\begin{array}{l}\text { Non-obese } \\
\text { women with an } \\
\text { elevated } \\
\text { fasting glucose } \\
\text { in the first or } \\
\text { early second } \\
\text { trimester } \\
\mathrm{N}=36 \text { (treated) } \\
\mathrm{N}=39 \text { (control) }\end{array}$ & $\mathrm{Ml}$ & $\begin{array}{l}\text { Lower } \\
\text { abnormal OGTT } \\
\text { and insulin } \\
\text { therapy }\end{array}$ & $\begin{array}{l}\text { Lower rates of } \\
\text { Polyhydramnios }\end{array}$ & $\begin{array}{l}\text { Lower neonatal } \\
\text { hypoglycemia, } \\
\text { birth weight, fetal } \\
\text { abdominal } \\
\text { circumference, } \\
\text { higher GA at } \\
\text { delivery }\end{array}$ \\
\hline $\begin{array}{l}\text { D'Anna } \\
\text { et al } 2013 \\
\text { [73] }\end{array}$ & $\begin{array}{l}\text { Outpatients } \\
\text { with a parent } \\
\text { with type } 2 \\
\text { diabetes } \\
\mathrm{N}=110 \text { each } \\
\text { group }\end{array}$ & $\mathrm{Ml}+\mathrm{FA}$ & $\begin{array}{l}\text { Lower GDM } \\
\text { rate }\end{array}$ & $\begin{array}{l}\text { No differences in } \\
\text { CS and PTB rates }\end{array}$ & $\begin{array}{l}\text { Significant } \\
\text { differences } \\
\text { between groups } \\
\text { on macrosomia } \\
\text { rate and birth } \\
\text { weight }\end{array}$ \\
\hline $\begin{array}{l}\text { Malvasi } \\
\text { et al } 2014 \\
{[74]}\end{array}$ & $\begin{array}{l}\text { Non-obese } \\
\text { healthy women } \\
\text { at } 13 \text { th -24th } \\
\text { week of } \\
\text { pregnancy } \\
\mathrm{N}=24 \text { each } \\
\text { group }\end{array}$ & $\mathrm{Ml}+\mathrm{DCl}+\mathrm{FA}+\mathrm{Mn}^{2+}$ & $\begin{array}{l}\text { Improvement } \\
\text { of glycemia and } \\
\text { blood } \\
\text { parameters } \\
\text { (except } \\
\text { diastolic blood } \\
\text { pressure }\end{array}$ & -- & -- \\
\hline $\begin{array}{l}\text { D'Anna } \\
\text { et al } 2015 \\
{[75]}\end{array}$ & $\begin{array}{l}\text { Obese women } \\
\text { at } 12-13 \\
\text { weeks of } \\
\text { gestation } \\
\mathrm{N}=110 \text { each } \\
\text { group }\end{array}$ & $\mathrm{Ml}+\mathrm{FA}$ & $\begin{array}{l}\text { Lower GDM } \\
\text { rate }\end{array}$ & $\begin{array}{l}\text { No differences in } \\
\text { CS and PTB rates }\end{array}$ & $\begin{array}{l}\text { No differences in } \\
\text { birth weight and } \\
\text { macrosomia }\end{array}$ \\
\hline $\begin{array}{l}\text { Santamaria } \\
\text { et al } 2016 \\
{[76]}\end{array}$ & $\begin{array}{l}\text { Overweight, } \\
\text { non-obese } \\
\text { women } \\
\mathrm{N}=110 \text { each } \\
\text { group }\end{array}$ & $\mathrm{Ml}+\mathrm{FA}$ & $\begin{array}{l}\text { Lower GDM } \\
\text { rate }\end{array}$ & $\begin{array}{l}\text { No differences in } \\
\text { CS and PTB rates }\end{array}$ & $\begin{array}{l}\text { No differences in } \\
\text { birth weight and } \\
\text { macrosomia }\end{array}$ \\
\hline $\begin{array}{l}\text { Lubin } \\
\text { et al } 2016 \\
{[77]}\end{array}$ & $\begin{array}{l}\text { Women with } \\
\text { GDM } \\
\text { uncontrolled } \\
\text { by diet } \\
\mathrm{N}=32 \text { (treated) } \\
\mathrm{N}=28 \text { (control) }\end{array}$ & $\mathrm{Ml}+\mathrm{FA}$ & $\begin{array}{l}\text { Lower need of } \\
\text { insulin } \\
\text { treatment }\end{array}$ & $\begin{array}{l}\text { Lower labour } \\
\text { induction }\end{array}$ & $\begin{array}{l}\text { No differences in } \\
\text { birth weight and } \\
\text { macrosomia }\end{array}$ \\
\hline $\begin{array}{l}\text { Farren } \\
\text { et al } 2017 \\
{[78]}\end{array}$ & $\begin{array}{l}\text { Women with a } \\
\text { family history } \\
\text { of diabetes } \\
\mathrm{N}=120 \text { each } \\
\text { group }\end{array}$ & $\mathrm{Ml}+\mathrm{DCl}+\mathrm{FA}$ & $\begin{array}{l}\text { No changes in } \\
\text { GDM rate }\end{array}$ & $\begin{array}{l}\text { No differences in } \\
\text { CS and PTB rates }\end{array}$ & $\begin{array}{l}\text { Higher incidence } \\
\text { of neonatal } \\
\text { hypoglycemia } \\
\text { and lower } \\
\text { neonatal jaundice }\end{array}$ \\
\hline
\end{tabular}




\begin{tabular}{|c|c|c|c|c|c|}
\hline $\begin{array}{l}\text { Fraticelli } \\
\text { et al } 2018 \\
\text { [79] }\end{array}$ & $\begin{array}{l}\text { Women with } \\
\text { GDM } \\
\mathrm{N}=20 \text { each } \\
\text { group }\end{array}$ & $\begin{array}{l}\mathrm{Ml}+\mathrm{FA} \\
\mathrm{DCl}+\mathrm{FA} \\
\mathrm{MI}+\mathrm{DCl}+\mathrm{FA}\end{array}$ & $\begin{array}{l}\text { Lower HOMA } \\
\text { index and } \\
\text { weight gain } \\
\text { with MI } \\
\text { Lower need for } \\
\text { insulin therapy } \\
\text { in } \mathrm{Ml} \text { and } \\
\mathrm{MI+DCl}\end{array}$ & $\begin{array}{l}\text { No differences in } \\
\text { CS, induction } \\
\text { and PTB rates }\end{array}$ & $\begin{array}{l}\text { Lower birth } \\
\text { weight in inositol } \\
\text { groups }\end{array}$ \\
\hline $\begin{array}{l}\text { Pintaudi } \\
\text { et al } 2018 \\
\text { [80] }\end{array}$ & $\begin{array}{l}\text { Women with } \\
\text { GDM } \\
\mathrm{N}=6 \text { each } \\
\text { group }\end{array}$ & $\mathrm{Ml}+\mathrm{FA}$ & $\begin{array}{l}\text { Reduction of } \\
\text { glucose } \\
\text { variability }\end{array}$ & $\begin{array}{l}\text { No differences in } \\
\text { CS and PTB rates }\end{array}$ & $\begin{array}{l}\text { No differences in } \\
\text { birth weight and } \\
\text { macrosomia }\end{array}$ \\
\hline $\begin{array}{l}\text { Celentano } \\
\text { et al } 2020 \\
{[65]}\end{array}$ & $\begin{array}{l}\text { Non-obese } \\
\text { women with } \\
\text { elevated } \\
\text { fasting glucose } \\
\text { in the first or } \\
\text { early second } \\
\text { trimester } \\
\mathrm{N}=105 \\
\text { (treated) } \\
\mathrm{N}=52 \text { (control) }\end{array}$ & $\begin{array}{l}\mathrm{MI} \\
\mathrm{DCl} \\
\mathrm{MI}+\mathrm{DCl}\end{array}$ & $\begin{array}{l}\text { Lower } \\
\text { abnormal OGTT } \\
\text { with MI }\end{array}$ & $\begin{array}{l}\text { No differences in } \\
\text { CS and PTB rates }\end{array}$ & $\begin{array}{l}\text { Lower birth } \\
\text { weight, fetal } \\
\text { abdominal } \\
\text { circumference, } \\
\text { and higher GA at } \\
\text { delivery with MI }\end{array}$ \\
\hline
\end{tabular}


Figure 1

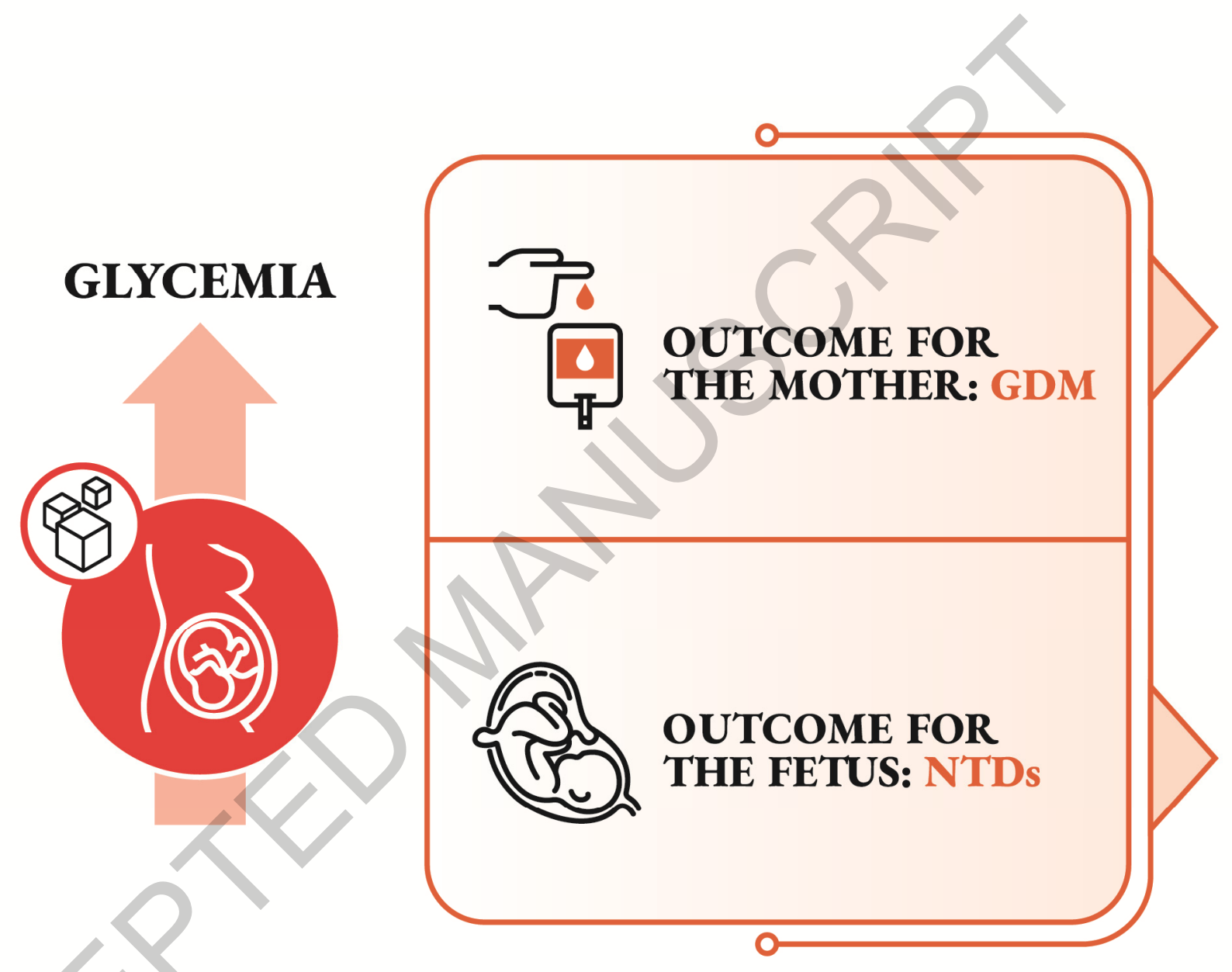

